\title{
Werkende armen in Nederland
}

\section{Transities in en uit werkende armoede}

Erik Snel1

Erik Snel is als universitair docent en onderzoeker verbonden aan de Department of Public Administration and Sociology (DPAS) van de Erasmus Universiteit Rotterdam. E-mail: snel@fsw.eur.nl

1.

De auteur bedankt Nienke Nottelman (O\&S Amsterdam) met wie dit onderzoek indertijd is uitgevoerd, en Salome Aussen en Aniek Julicher die behulpzaam waren bij het coderen en analyseren van de kwalitatieve interviews. Verder dank ik de reviewers van Mens \& Maatschappij voor hun zorgvuldig lezen en constructief commentaar leveren op een eerdere versie van dit artikel.

\section{SUMMARY}

Go to section.

TOPSUMMARY1 INLEIDING2 WERKENDE ARMOEDE: ONTWIKKELING EN ACHTERGRONDEN3 WIE ZIJN DE WERKENDE ARMEN IN NEDERLAND?4 ONDERZOEKSMETHODE5 WERKENDE MINIMA IN AMSTERDAM6 HOE KOMEN MENSEN IN WERKENDE ARMOEDE TERECHT?7 UIT DE ARMOEDE GEWERKT8 CONCLUSIES EN DISCUSSIEGERAADPLEEGDE LITERATUURWorking poor in the Netherlands: Transitions in and out of the working poor

The Netherlands has increasing numbers of working poor. Recent figures show that one in twenty working individuals in the Netherlands lives in a household below the poverty threshold. In Amsterdam, the in-work poverty risk is even higher than average; the reason for this research. The Amsterdam working poor are a heterogeneous category. Half of them have permanent contracts; a large minority works at least 30 hours a week. They work in sectors like transport, shops, catering, but also in public services. Many, but not all working poor are poorly educated. Are they the victims of activating labour market policies that push low-skilled workers on the labour market without escaping from poverty? This appears not to be the case. Less than half of the working poor in Amsterdam entered this situation after having a social benefit. The majority of these former social benefit claimants say they did not experience any pressure to accept low-paid work instead of a social benefit. The other working poor entered this situation from some other employment or directly from school. Respondents mention three factors as reasons of becoming working poor: physical or mental health problems, child care responsibilities, and deficient education. More often, it is a combination of unfavourable factors that results in in-work poverty.

\section{Keywords}

$\bullet$ poverty,

-working poor,

-causes of poverty,

-Amsterdam

\section{INLEIDING}


TOPSUMMARY1 INLEIDING2 WERKENDE ARMOEDE: ONTWIKKELING EN ACHTERGRONDEN3 WIE ZIJN DE WERKENDE ARMEN IN NEDERLAND?4 ONDERZOEKSMETHODE5 WERKENDE MINIMA IN AMSTERDAM6 HOE KOMEN MENSEN IN WERKENDE ARMOEDE TERECHT?7 UIT DE ARMOEDE GEWERKT8 CONCLUSIES EN DISCUSSIEGERAADPLEEGDE

LITERATUURBetaald werk geldt als dé oplossing voor armoede in het Nederlandse armoedebeleid. Uitgangspunt is dat werk moet lonen en dat een voltijdbaan in principe voldoende inkomen oplevert om als volwaardig burger in de samenleving te kunnen participeren. De vraag is echter of werk altijd een ontsnapping uit armoede betekent. Zowel in de pers (Stoker 2010; Tinnemans 2009; Van de Pol 2016) als in de sociaalwetenschappelijke literatuur (Andreß \& Lohman 2008; Hoff, Wildeboer Schut, Goderis \& Vrooman 2016; Josten 2007; Schraad-Tischler \& Schiller 2016; Snel, De Boom \& Engbersen 2008; Snel \& De Boom 2008; Wildeboer Schut \& Hoff 2016) verschijnen de laatste jaren berichten over het groeiende aantal werkende armen in Nederland en elders in Europa. Hierna bespreken we diverse aspecten van deze ontwikkeling. Hoe groot is hun aantal? Wie betreft het? En welke verklaringen biedt de literatuur voor de groeiende werkende armoede in Nederland? De centrale vraagstelling in dit artikel is echter anders. Indachtig de woorden van de Belgische armoedeonderzoekers Levecque en Vranken (2000: 41) dat er in het dominante kwantitatieve armoedeonderzoek ‘... veel wordt gecijferd over de hoogte van armoedegrenzen en de aantallen armen, maar dat systematisch onderzoek naar de belangrijkste factoren die armoede veroorzaken (...) ontbreekt', stellen we hier de vraag: hoe zijn mensen in de situatie van werkende armoede terechtkomen? En hoe slaagden sommigen van hen erin uit werkende armoede te ontsnappen?

De hier gebruikte gegevens zijn afkomstig uit een onderzoek onder werkende minima in Amsterdam. Concrete aanleiding voor dit onderzoek waren berekeningen van de Dienst O\&S dat Amsterdam in 2005 tussen 25.000 en 26.000 werkende armen telde (dat wil zeggen: werkenden levend in een huishouden dat moet rondkomen van een laag inkomen). Hiermee lag het armoederisico voor werkenden in Amsterdam aanmerkelijk hoger dan het landelijk gemiddelde (Snel, Slot \& Nottelman 2012: 9; vgl. O\&S 2010: 21-25). In ons onderzoek konden we een aantal werkende armen in Amsterdam benaderen voor een interview $(N=109)$. We vroegen hen over allerlei aspecten van werkende armoede, maar de centrale vraag was hoe zij in de situatie van 
werkende armoede waren terechtgekomen. Sommigen van hen $(N=20)$ hadden inmiddels uit werkende armoede kunnen ontsnappen: ze werkten nog steeds, maar waren niet meer arm. We vroegen hen hoe ze hierin waren geslaagd. Overigens gebruikten we de beladen term 'armoede' niet in onze interviews. We spraken van 'werken voor een bescheiden inkomen' (vgl. Snel e.a. 2012).

De wetenschappelijke relevantie van dit artikel ligt in het inzicht dat het biedt in de processen waardoor werkenden in een armoedesituatie terechtkomen en waardoor sommigen van hen erin slagen uit werkende armoede te ontsnappen. Zulke processen komen niet naar voren in het in Nederland dominante kwantitatieve armoedeonderzoek. De beleidsmatige relevantie ligt in de huidige aanpak van het armoedebeleid waarin betaald werk veelal als oplossing voor armoede wordt gezien. Critici betogen dat werk niet altijd een ontsnapping uit armoede betekent: sommige werkenden, zoals het merendeel van de respondenten van dit onderzoek, blijven gevangen in armoede. Wel zal blijken dat slechts enkelen van hen vanuit een uitkeringssituatie in werkende armoede terechtkwam.

De opbouw van dit artikel is als volgt. We beginnen met een schets van ontwikkeling en achtergrond van de toenemende werkende armoede in Nederland en in Europa (par. 2). Vervolgens bespreken we wat op grond van eerder onderzoek bekend is over werkende armen in Nederland (par. 3). Daarna bespreken we onze onderzoeksopzet (par. 4). In de analyse gaan we zowel in op factoren die verklaren waarom onze respondenten in de situatie van werkende armoede terechtkwamen (par. 5) als op hoe sommigen uit deze situatie konden ontsnappen (par. 6). We eindigen met een discussie van onze bevindingen (par. 7).

\section{WERKENDE ARMOEDE: ONTWIKKELING EN} ACHTERGRONDEN

Go to section.

TOPSUMMARY1 INLEIDING2 WERKENDE ARMOEDE: ONTWIKKELING EN ACHTERGRONDEN3 WIE ZIJN DE WERKENDE ARMEN IN NEDERLAND?4 ONDERZOEKSMETHODE5 WERKENDE MINIMA IN AMSTERDAM6 HOE KOMEN MENSEN IN WERKENDE ARMOEDE TERECHT?7 UIT DE ARMOEDE GEWERKT8 CONCLUSIES EN DISCUSSIEGERAADPLEEGDE

LITERATUURTot niet lang geleden dachten we dat de 'working poor' een 
typisch fenomeen was van liberale verzorgingsstaten zoals de Verenigde Staten. De combinatie van marginale sociale zekerheid en lage minimumlonen in de VS leidt ertoe dat kwetsbare personen wel gedwongen zijn om te werken, maar desondanks arm blijven (Esping-Andersen 1990). Etnografisch onderzoek laat zien dat de Amerikaanse werkende armen vaak meerdere laagbetaalde banen moeten combineren om te kunnen rondkomen (Ehrenreich 2002; Newman 1999). Sinds eind jaren negentig wordt echter ook in Europa gesproken van werkende armen. Kort na de millenniumwisseling had 7 procent van de werkenden in de Europese Unie (EU-15) een inkomen onder de armoedegrens van het betreffende land (Bardone \& Guio 2005), in 2005 was dit aandeel opgelopen tot 8,2 procent en in 2015 tot 9,5 procent. In landen als Griekenland en Roemenië lag het aandeel armen onder de werkenden nog aanmerkelijk hoger (respectievelijk 13,4 en 18,8 procent).?

\section{Gegevens:}

http://ec.europa.eu/eurostat/tgm/table.do?tab=table\&init=1\&language=en\&pcod $\underline{\mathrm{e}=\text { tsdsc320\&plugin }=1}$

Ook in Nederland verschenen rond de millenniumwisseling de eerste berichten over het groeiende aantal werkende armen in ons land (De Beer 1999; Snel, Engbersen \& Vrooman 2000). Josten (2007: 79) becijferde dat Nederland in de periode 2002-2004 ruim 280.000 werkende armen telde. Concreet betekende dit dat pakweg één op de 25 werkenden in Nederland een inkomen onder de armoedegrens had. Bij zelfstandigen lag de kans op armoede nog aanmerkelijk hoger (rond één op de acht). Josten (2007: 83) liet ook zien dat het aantal werkende armen in Nederland tussen 1990 en 2005 in absolute aantallen meer dan verdubbeld is (van 147.000 tot 310.000). Aangezien echter ook het totale aantal werkenden in deze jaren was gegroeid, bleef het relatieve armoederisico van werkenden - het aandeel werkenden met een inkomen onder de armoedegrens - min of meer gelijk. Dit schommelde 1996 en 2005 tussen de 5,3 en 6,5 procent. Volgens de meest recente gegevens (uit 2014) is het aantal werkende armen in Nederland opgelopen tot 366.000. lets meer dan de helft van hen betreft werkenden in loondienst, iets minder dan de helft zijn zelfstandigen. Hiermee is het relatieve armoederisico van werkenden anno 2014 opgelopen tot 4,8 procent (Hoff e.a. 2016: 31, 32). Met een armoederisico van werkenden rond 5 procent komt Nederland binnen de Europese Uniea (EU- 
28) op de vijfde plaats als land met relatief de minste werkende armen (na

Finland, lerland, België, Tsjechië, Denemarken en Malta) (Schraad-Tischler \&

Schiller 2016: 45). $\cdot$

3.Volgens Eurostat had 5 procent van alle werkenden in Nederland in 2015 een inkomen onder de armoedegrens. (zie

http://ec.europa.eu/eurostat/tgm/table.do?tab=table\&init=1\&language=en\&pcod e=tsdsc320\&plugin=1). Volgens Schraad-Tischler en Schiller (2016) ligt het aandeel armen onder de werkenden in Nederland nog iets hoger (5,2 procent).

Het probleem met deze cijfers over werkende armen is echter dat ze sterk beïnvloed worden door de gehanteerde armoedegrenzen. In het Nederlandse en internationale armoedeonderzoek worden namelijk verschillende armoedegrenzen gebruikt. Over het algemeen geldt hierbij: hoe hoger de gehanteerde armoedegrens, hoe hoger ook het aantal huishoudens dat eronder valt. Oorspronkelijk werd in het Nederlandse armoedeonderzoek veelal uitgegaan van een huishoudinkomen onder of rond (maximaal 5 procent boven) het sociaal minimum zoals vastgelegd in de socialezekerheidswetgeving (WWB, AOW). Het sociaal minimum voor (echt)paren en samenwonenden komt ongeveer overeen met het wettelijk minimumloon en bedroeg in 2014 bijna 1360 euro. Voor eenoudergezinnen lag het sociaal minimum op 70 procent van dit bedrag (952 euro) en voor alleenwonenden op 50 procent (680 euro). 4

\section{4.https://www.rijksoverheid.nl/actueel/nieuws/2014/06/25/uitkeringsbedragen-}

per-1-juli-2014 (gezien 21 februari 2017).

Het Sociaal en Cultureel Planbureau hanteert echter een andere armoedegrens, namelijk de zogenaamde budget-methode. Op basis van een door deskundigen samengestelde lijst met minimaal noodzakelijke goederen en voorzieningen berekent men welk budget minimaal noodzakelijk is voor een huishouden om in het levensonderhoud te voorzien. Men maakt hierbij nog een onderscheid tussen twee varianten: de minimaal noodzakelijke kosten ('basisbehoeften') en deze kosten plus uitgaven voor sociale participatie ('nietveel-maar-toereikend'). De bij deze armoedegrenzen behorende bedragen lagen net iets hoger dan de zojuist genoemde bedragen van het sociaal minimum (

5.In 2014 bedroeg de armoedegrens voor een paar met 1 kind volgens deze methode 1620 euro per maand volgens het 'basisbehoeften'-criterium en 1780 euro volgens het 'niet-veel-maar-toereikend'-criterium. Voor een alleenstaande 
ouder met 1 kind waren deze bedragen 1300 resp. 1410 euro, voor een alleenwonende 971 resp. 1063 euro (Hoff e.a. 2016: 12).

In internationaal vergelijkend onderzoek wordt ten slotte meestal een relatieve armoedegrens gehanteerd. Een huishouden geldt als arm als het huishoudinkomen lager ligt dan 60 procent van het mediane huishoudinkomen in het betreffende land.

Hoe dit ook is gemeten, duidelijk is dat zowel het absolute aantal als het relatieve aandeel werkende armen de afgelopen decennia is gestegen, zowel in Nederland als elders in Europa. Dit lijkt het gevolg van een combinatie van economische, beleidsmatige en maatschappelijke ontwikkelingen (Andre $\beta$ \& Lohmann 2008: 1-6). Ten eerste hangt de toegenomen armoede onder werkenden samen met de overgang van een 'fordistische' naar een 'postfordistische' economie: de overgang van een overwegend industriële economie waarin werknemers veelal vast en redelijk betaald werk hadden (mede door de sterke positie van vakbonden) naar een postindustriële diensteneconomie waarin, naast een professionele elite, er toenemend laagbetaalde, onzekere en (zeker in Nederland) parttime banen zijn. Esping-Andersen (1993) duidt deze laatste categorie werkenden aan als het 'postindustrial service proletariat'. Juist onder hen zouden er veel werkende armen zijn. Ook de mondialisering van de economie, waardoor laaggeschoolde arbeid in westerse landen moet concurreren met laaggeschoolde arbeid in ontwikkelingslanden, zou bijdragen tot meer werkende armoede. Ten slotte zou de recente arbeidsmigratie uit Midden- en Oost-Europa een drukkend effect op de lonen in Nederland hebben, waardoor meer werkenden een gering inkomen hebben.

Daarnaast speelt het sociaal beleid van Europese verzorgingsstaten een rol bij het groeiend aantal werkende armen. Vanwege bezuinigingen én om ideologische redenen zien we in veel Europese landen een politiek van beperking van uitkeringen, meer selectieve toegang tot sociale zekerheid en maatregelen om de uitstroom van uitkering naar werk te bevorderen. Gilbert (2002) spreekt van de transformatie van de traditionele verzorgingsstaat, primair gericht op de bescherming van kwetsbare groepen, naar de 'enabling state', die primair gericht is op sociale inclusie middels betaalde arbeid. Als uitkeringsontvanger, vooral degenen met een kwetsbare arbeidsmarktpositie (laag geschoold, lang werkloos, grote afstand tot de arbeidsmarkt) sterker geprikkeld worden om te gaan werken, kan ook dit tot een toename van 
werkende armoede leiden (vgl. Snel e.a. 2008). Andreß en Lohmann (2008: 11) noemen Nederland de 'continental frontrunner' van deze politiek, hetgeen mede zou verklaren waarom het aandeel werkende armen bij ons hoger ligt dan in andere Europese landen:

If we take Belgium as a country of comparison, which consequently keeps some of the risk groups out of the labour market, the Netherlands, in contrast, has fundamentally altered its policies and opted for a strategy of labour market inclusion. As a consequence, the Netherlands not only stands out with its high in-work poverty rate, but also because of the fact that more than half of the poor are working poor (Lohmann \& Andreß 2008: 303).

Verder is er volgens Lohmann en Andre $\beta$ (2008: 305-6) ook een verband tussen het aandeel werkende armen en de positie van de vakbeweging in een land. Landen als België, Denemarken en Finland hebben een vrij sterke 'union density' en relatief weinig werkende armoede, terwijl landen als Nederland en Griekenland een geringe 'union density' en relatief meer werkende armen hebben.

Bovenstaande factoren verklaren de groei van laagbetaald werk in Nederland en Europa, maar nog niet het groeiend aantal werkende armen. Laagbetaald werk is namelijk niet hetzelfde als armoede. Laagbetaald werk is een individueel kenmerk, armoede - dat wordt afgemeten aan de hoogte van het huishoudinkomen - is een kenmerk van huishoudens. Ook volgens Andre $\beta$ en Lohmann (2008: 3) bestaat er slechts een zwak verband tussen het voorkomen van laagbetaald werk in een land en werkende armoede. Zo kent het Verenigd Koninkrijk relatief veel laagbetaald werk, maar weinig werkende armoede. Kennelijk komen in de huishoudens van personen met laagbetaald werk ook andere inkomens binnen, waardoor het huishoudinkomen boven de armoedegrens komt. Werkende armoede komt dan ook vooral voor bij huishoudens met slechts één arbeidsinkomen, dat wil zeggen bij alleenstaanden, eenoudergezinnen en bij traditionele kostwinners die van één arbeidsinkomen een heel gezin onderhouden. De toegenomen werkende armoede in Nederland en Europa hangt daarom niet alleen samen met laagbetaald werk, maar ook met demografische en maatschappelijke 
ontwikkelingen, zoals het groeiende aantal alleenstaanden en

eenoudergezinnen of de toename van parttime werk, vooral bij vrouwen die werk en zorg combineren. Als zij niet veel verdienen en geen meeverdienende partner hebben, vallen zij al snel onder de armoedegrens.

\section{WIE ZIJN DE WERKENDE ARMEN IN NEDERLAND?}

TOPSUMMARY1 INLEIDING2 WERKENDE ARMOEDE: ONTWIKKELING EN ACHTERGRONDEN3 WIE ZIJN DE WERKENDE ARMEN IN NEDERLAND?4 ONDERZOEKSMETHODE5 WERKENDE MINIMA IN AMSTERDAM6 HOE KOMEN MENSEN IN WERKENDE ARMOEDE TERECHT?7 UIT DE ARMOEDE GEWERKT8 CONCLUSIES EN DISCUSSIEGERAADPLEEGDE

LITERATUURWat weten we over de kenmerken van de werkende armen in Nederland? We zagen al dat zelfstandigen een aanmerkelijk hoger armoederisico lopen dan werknemers. Daarnaast zijn parttime werkenden een belangrijke risicogroep. Vooral werknemers met een kleine baan (hooguit 24 uur per week) lopen een hoog risico op werkende armoede. We weten bovendien dat het armoederisico van parttimers sinds midden jaren tachtig verdrievoudigd is. Werkende armoede blijft echter niet tot deze categorie beperkt. Ook fulltime werkenden hebben een zeker risico op werkende armoede, vooral als er geen andere inkomens in het huishouden zijn (Josten 2007; Snel e.a. 2008). Werkende armoede blijft ook niet beperkt tot één bepaalde beroepssector. De werkende armen zijn niet alleen mensen met laaggekwalificeerde, flexibele dienstenbaantjes maar evenzeer personen met een meer traditioneel 'fordistisch' beroep (Snel e.a. 2008: 138, 146).

De kans op werkende armoede hangt daarnaast samen met diverse persoonskenmerken: vrouwen, eenoudergezinnen, laaggeschoolden, nietwesterse migranten en meer algemeen huishoudens met slechts één arbeidsinkomen zijn bovengemiddeld vaak werkend arm (Josten 2007; Snel e.a. 2008). In de praktijk gaat het echter veelal om een combinatie van ongunstige factoren waardoor mensen werkend arm zijn. Snel e.a. (2008: 145) laten zien dat vrouwen op zich geen verhoogd risico op werkende armoede lopen. Wanneer in een multivariate analyse rekening wordt gehouden met andere factoren lopen vrouwen geen hoger risico op werkende armoede dan mannen. Dat vrouwen een verhoogde kans op werkende armoede hebben, komt doordat zij vaker parttime werken, lager geschoold zijn, in een eenoudergezin c.q. een huishouden met slechts één inkomen leven. Vooral dit 
laatste blijkt cruciaal om werkende armoede te verklaren. Werkende armoede komt bijna uitsluitend voor bij 'eenverdieners'; met meerdere inkomens in een huishouden, hoe laag die ook zijn, komt men doorgaans wel boven de armoedegrens (Snel e.a. 2008: 145). Hiermee lopen zowel traditionele als nieuwe sociale categorieën een verhoogd risico op werkende armoede. Enerzijds de traditionele kostwinners (veelal mannen met een migratieachtergrond) die met één laagbetaalde baan hun gezin onderhouden, anderzijds alleenstaande ouders (veelal vrouwen) die vanwege de combinatie van werk en zorg onvoldoende uren kunnen werken om een inkomen boven de armoedegrens te verdienen.

Een andere vraag betreft de duur van werkende armoede. Om wat voor werkende armen gaat het? Zijn het werkenden die om min of meer toevallige redenen (bijv. veranderende huishoudsituatie, slechts een deel van het jaar werkend, bijvoorbeeld na afstuderen, baanverlies of ziekte) veelal tijdelijk een jaartje arm zijn? Of betreft het werkenden die er jaar in jaar uit niet in slagen een inkomen boven de armoedegrens te verwerven? Longitudinaal onderzoek van Snel en De Boom (2008) liet zien dat werkende armoede in Nederland vaak slechts tijdelijk is. Ze vonden dat 14 procent van alle werkenden in Nederland in de door hen onderzochte periode (1995-2005) minstens één jaar werkend arm was. Voor ruim de helft van hen (58 procent van alle werkende armen) bleef deze ervaring beperkt tot één jaar. De andere jaren werkte men niet of was men niet arm. Eén op de vijf (21 procent) werkende armen verkeerde echter drie jaar of langer in deze onfortuinlijke situatie. Voor hen was werkende armoede geen voorbijgaand incident, maar een structureel probleem. $\underline{6}$

6.Snel en De Boom (2008) meten armoede volgens de Europese armoede grens. Een huishouden geldt hierbij als 'arm' als het huishoudinkomen lager is dan 60 procent van het mediane huishoudinkomen in het betreffende jaar. In de analyse werd geteld hoe vaak een persoon gedurende tien jaar tijd werkend arm was. Deze analyse heeft twee beperkingen. Ten eerste werd niet duidelijk wat de situatie van deze persoon in de andere jaren was: was men werkend en niet arm (ontsnapt uit armoede) óf was men nog steeds arm, maar niet werkend. Ten tweede kon bij personen die meerdere jaren arm waren niet 
worden vastgesteld of dit een aaneengesloten periode was. Was men gedurende langere tijd werkend arm of viel men steeds terug in armoede?

Dit laatste wordt bevestigd in recent onderzoek van Wildeboer Schut en (2016). Inkomensgegevens over een langere periode (1990-2012) beziend, vonden zij dat tussen 25 en 30 procent (dit verschilt per jaar) van alle werkenden met een inkomen onder de armoedegrens slechts kort (1 jaar) in deze situatie verkeerde. Een groter deel van de werkende armen (35 tot 40 procent) zat echter minimaal drie jaar achtereen onder de armoedegrens. Langdurige armoede onder werkenden is vooral toegenomen na de economische crisis van 2008 (Wildeboer Schut \& Hoff 2016: 40, 48).?

7.Dat Wildeboer Schut en Hoff (2016) tot andere uitkomsten over de duur van werkende armoede komen dan Snel en De Boom (2008) kan allerlei redenen hebben. Niet alleen onderzochten Snel en De Boom een andere periode dan Wildeboer Schut en Hoff (1995-2005 versus 1991-2011), ook hanteerden zij een andere armoedegrens (60 procent van het mediane huishoudinkomen versus de eerder benoemde budgetgrenzen van het SCP) en stelden zij de armoededuur op andere wijze vast. Snel en De Boom bekeken hoe vaak een persoon in tien jaar tijd werkend én arm was. Wildeboer Schut en Hoff bekeken of een persoon die in een bepaald jaar werkend arm was in eerdere of latere jaren ook arm was (al dan niet werkend).

\section{ONDERZOEKSMETHODE}

Go to section.

TOPSUMMARY1 INLEIDING2 WERKENDE ARMOEDE: ONTWIKKELING EN ACHTERGRONDEN3 WIE ZIJN DE WERKENDE ARMEN IN NEDERLAND?4 ONDERZOEKSMETHODE5 WERKENDE MINIMA IN AMSTERDAM6 HOE KOMEN MENSEN IN WERKENDE ARMOEDE TERECHT?7 UIT DE ARMOEDE GEWERKT8 CONCLUSIES EN DISCUSSIEGERAADPLEEGDE

LITERATUURHet doel van dit onderzoek was inzicht te verkrijgen wie de werkende armen in Amsterdam zijn, maar vooral ook hoe zij in de situatie van werkende armoede waren terechtgekomen en hoe sommigen van hen uit armoede hadden kunnen ontsnappen. We wilden dus transities in en uit werkende armoede onderzoeken. Hierom gingen we op zoek naar twee categorieën werkende minima, namelijk personen die in twee jaren (2008 en 2009) werkend arm waren én personen die in 2008 werkend arm waren en in 2009 nog steeds werkten, maar niet meer arm waren. Of iemand arm was, werd vastgesteld aan de hand van de in Amsterdam gangbare armoedegrens. lemand geldt hierbij als 'arm' wanneer zijn huishoudinkomen lager is dan 110 procent van het relevante bijstandsinkomen (zoals reeds uitgelegd, verschilt dat per type huishouden). Het steekproefkader voor onze survey kwam tot 
stand doordat inkomensgegevens van de Amsterdamse Dienst Werk \& Inkomen (DWI) gekoppeld konden worden aan gegevens van UWV over werkenden in de stad. In totaal voldeden 7457 personen aan beide criteria (in 2008 werkend arm, in 2009 in ieder geval nog werkend). Dit aantal ligt om meerdere redenen lager dan het eerder genoemde aantal van 25.000 werkende minima in Amsterdam. Ten eerste wilden we geen studenten en pas afgestudeerden in ons onderzoek betrekken omdat dit een relatief kansrijke categorie is. Daarom vielen werkende minima jonger dan 30 jaar buiten onze doelgroep. Ten tweede werkten nogal wat werkende minima uit 2008 een jaar later niet meer of ze waren inmiddels verhuisd, overleden of met pensioen gegaan en vielen om die reden af. Ten slotte gaan de UWV-gegevens alleen over werkenden in loondienst en niet over zelfstandigen (tenzij ze daarnaast in loondienst werkten). Daarom vielen ook zelfstandigen onder de armoedegrens af als mogelijke respondenten van dit onderzoek.

Onze interviewers waren getraind om kwalitatieve interviews af te nemen. Ze gingen op pad met semigestructureerde vragenlijsten met vragen over achtergrondkenmerken, werk- en inkomenssituatie van respondenten én eventuele veranderingen daarin. Op twee punten was sprake van een open interviewsituatie. We vroegen de respondenten waarom ze naar hun eigen mening in de situatie van werkende armoede waren terechtgekomen en, als daar volgens onze gegevens sprake van was, waarom ze het in 2009 financieel beter hadden gekregen. Deze antwoorden werden opgenomen en achteraf door de interviewers letterlijk uitgewerkt. Daarnaast werd de respondenten ook gevraagd wat naar hun mening de belangrijkste reden was waarom ze in de situatie van werkende armoede waren terechtgekomen c.q. uit deze situatie konden ontsnappen. Hierbij kon men uit diverse mogelijke redenen kiezen, maar ook eigen redenen opgeven, die achteraf door ons werden gecodeerd.

Het veldwerk voor dit onderzoek vond plaats in 2011. In totaal werden 109 respondenten geïnterviewd, een respons van 8 procent van alle benaderde personen. $\stackrel{8}{-}$

8.De omvang van de steekproef was aanvankelijk 750, later aangevuld tot 1000 . De steekproeven zijn niet volledig uitgeput. De procedure was dat respondenten een schriftelijke uitnodiging van de gemeente kregen om zich zelf te melden voor een interview. Toen dit onvoldoende respons opleverde, zijn 
beoogde respondenten ook zonder dat ze zichzelf hadden gemeld door ons benaderd voor een interview. Hierbij bleek dat respondenten vaker dan gemiddeld negatief reageerden op het verzoek om deel te nemen. Dit alles bevestigt het beeld dat deze doelgroep niet makkelijk benaderbaar is voor onderzoek.

Voor zover wij konden nagaan vormde onze respondentengroep, hoewel relatief klein, op cruciale variabelen zoals leeftijd, geslacht en etnische achtergrond, een redelijke afspiegeling van het steekproefkader (zie hierna tabel 1). Wel hebben wij, vergeleken met het steekproefkader, verhoudingsgewijs wat meer autochtone werkende armen geïnterviewd en wat minder Turkse en (vooral) Marokkaanse. Ook hebben wij verhoudingsgewijs wat minder paren met kinderen en wat meer alleenstaande ouders (merendeels moeders) geïnterviewd.

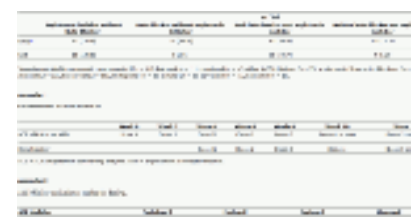

Tabel 1 Click to view

Tabel 1

Achtergrondkenmerken van respondenten (in \%)

We hadden ons ten doel gesteld om in totaal 150 personen te interviewen, waarvan de helft in beide jaren werkend arm was en de andere helft in 2009 nog steeds werkte, maar niet meer arm was. Dit is om een aantal redenen niet gelukt. Ten eerste lukte het door de geringe respons niet om 150 werkende minima uit 2008 te interviewen. Ten tweede lag de verhouding tussen beide deelgroepen heel anders dan we op grond van de beschikbare registratiegegevens hadden verwacht. Uiteindelijk behoorden slechts 20 personen (18 procent) naar eigen beleving tot de tweede deelgroep (in beide jaren werkend, in 2009 niet meer arm). Van de 109 respondenten werkten er acht niet in 2009 (hoewel ze volgens UWV-gegevens in dat jaar wel werkten). De resterende 81 respondenten (74 procent van het totaal) gaven zelf aan dat ze het in 2009 financieel niet beter hadden gekregen dan in 2008 (hoewel ze volgens onze inkomensgegevens in dat jaar niet meer arm waren). Naar het waarom van deze kloof tussen de geregistreerde en ervaren werkelijkheid kunnen we slechts gissen. Wellicht zijn de registraties niet adequaat of houden ze onvoldoende rekening met de grote dynamiek rond de armoedegrens. 
Huishoudens kunnen al met een geringe inkomensstijging boven de armoedegrens uitstijgen zonder dat ze het zelf als een financiële verbetering ervaren. Wellicht was dit bij sommige respondenten het geval. Ze hadden in 2009 een iets hoger inkomen dan in 2008 en waren daarom formeel niet meer arm, maar ze zagen zelf geen financiële verbetering.

\section{WERKENDE MINIMA IN AMSTERDAM}

\section{Go to section...}

TOPSUMMARY1 INLEIDING2 WERKENDE ARMOEDE: ONTWIKKELING EN ACHTERGRONDEN3 WIE ZIJN DE WERKENDE ARMEN IN NEDERLAND?4 ONDERZOEKSMETHODE5 WERKENDE MINIMA IN AMSTERDAM6 HOE KOMEN MENSEN IN WERKENDE ARMOEDE TERECHT?7 UIT DE ARMOEDE GEWERKT8 CONCLUSIES EN DISCUSSIEGERAADPLEEGDE

LITERATUURWie zijn de Amsterdamse werkende minima en wat voor soort werk doen ze? Tabel 1 geeft een overzicht van diverse achtergrondkenmerken van onze respondenten $(\mathrm{N}=109)$. In de tweede kolom staan dezelfde kenmerken van het steekproefkader $(\mathrm{N}=7457)$ vermeld.

Twee derde van de respondenten is vrouw. Qua leeftijd valt op dat het niet de jongste leeftijdscategorieën betreft: bijna driekwart van de respondenten is 40 jaar of ouder (dit komt ook doordat alleen personen vanaf 30 jaar zijn geïnterviewd). Qua huishoudsituatie zijn eenoudergezinnen de grootste groep (47 procent). Bij het steekproefkader lag het aandeel eenoudergezinnen overigens wat lager (35 procent). Een kwart van de respondenten is alleenstaand en eveneens een kwart betreft een paar met kinderen (in het steekproefkader was dit 36 procent). Paren zonder kinderen of andere huishoudvormen (zoals uitgebreide familiehuishoudens) treft men weinig aan bij de werkende armen.

We hebben zowel autochtone Nederlanders en als personen met een migratieachtergrond geïnterviewd. Ruim een derde van de respondenten (in het steekproefkader ruim een kwart) is autochtoon. Opvallend is het hoge aandeel Surinaamse en Antilliaanse Nederlanders. Het aandeel Marokkaanse en Turkse Nederlanders onder de werkende minima is daarentegen laag. Vooral dit laatste is opvallend omdat Amsterdam relatief veel Turkse zelfstandigen telt, waarvan gevreesd wordt dat ze vaak arm zijn. Dit blijkt niet uit onze cijfers. Dit komt waarschijnlijk vooral doordat onze steekproef maar weinig zelfstandigen telt (alleen degenen die daarnaast ook in loondienst werkten). Tabel 1 maakt 
verder duidelijk dat werkende minima niet alleen laaggeschoolden zijn: bijna twee derde van de respondenten heeft een middelbare opleiding afgerond (havo, vwo of mbo). Eén op de vijf heeft zelfs een hbo- of universitair diploma op zak.

We vroegen de respondenten over hun arbeidssituatie in 2008 (zie tabel 2). Bijna de helft van hen had een vast contract, de anderen hadden een tijdelijk of een nul-urencontract óf werkten voor een uitzendbureau of als zelfstandige. Het gaat zeker niet alleen om personen met 'kleine baantjes': bijna de helft van de respondenten werkte minimaal 30 uur per week, nog eens één op de vijf werkte tussen de 24 en 29 uur per week. Werkende armoede lijkt dus niet direct samen te hangen met de trend van flexibilisering van de arbeid. Niet-flexibele arbeidsrelaties (tijdelijke aanstelling, oproepkrachten, kleine baantjes, etc.) zijn dus kenmerkend voor de Amsterdamse werkende minima. Werkende armoede komt net zo vaak voor bij werkenden met een vast contract en een relatief grote baan (30 uur per week of meer). Veel werkende minima in Amsterdam werkten in de zakelijke dienstverlening, horeca en overige dienstverlening. Dit zijn sectoren met veel laagbetaald en parttime werk. Opvallend is dat een aanzienlijke minderheid van de respondenten (44 procent) voor 'de overheid' werkt en dat bijna één op de tien in de kunstsector werkt. Overigens zijn dit veelal geen kunstenaars (slechts één informant), maar bijvoorbeeld garderobemedewerkers of kaartjesverkopers in het Muziekgebouw of de Amsterdamse poptempel Paradiso. Meer algemeen werken de respondenten in zeer uiteenlopende beroepen (gegevens niet in tabel). Veel respondenten hebben een dienstenberoep, zoals schoonmaker, barkeeper, taxichauffeur, winkelbediende, medewerker in kinderopvang of thuiszorg. Dit zijn beroepen die passen bij de postindustriële economie van de stad. Ten slotte valt op dat sommige werkende minima redelijk hooggekwalificeerd werk hebben zoals diverse functies in het onderwijs of de gezondheidszorg (zoals een parttimewerkende activiteitenbegeleidster, een doktersassistente en een assistentpsychiater)

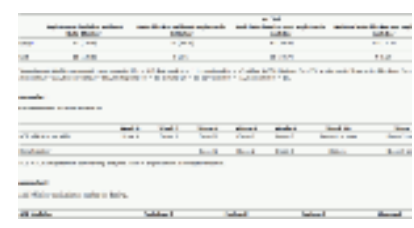


Tabel 2 vermeldt ook de arbeidssituatie van respondenten voorafgaand aan het werk dat ze in 2008 deden. Dit geeft een eerste indicatie hoe werkende minima in deze situatie zijn terechtgekomen, en vooral of ze vanuit een uitkering in de situatie van werkende armoede terechtkwamen. Dit laatste is voor 40 procent van de respondenten het geval. Een groter deel van hen (49 procent) was echter al werkzaam voordat ze in hun werk van 2008 terechtkwamen. De anderen (10 procent) kwamen direct vanuit het onderwijs of een andere situatie zonder werk in hun werk van 2008 terecht. We vroegen de respondenten die vanuit een uitkeringssituatie in werkende armoede waren terechtgekomen $(\mathrm{N}=$ 40) of ze druk hadden ervaren om het werk van 2008 te accepteren. Hun ervaringen waren verschillend. Eén op de drie respondenten die deze vraag beantwoordden, had enige tot sterke druk vanuit de uitkeringsinstantie ervaren om aan het werk te gaan, maar de anderen hadden weinig of geen druk ervaren.

\section{HOE KOMEN MENSEN IN WERKENDE ARMOEDE TERECHT?}

Go to section.

TOPSUMMARY1 INLEIDING2 WERKENDE ARMOEDE: ONTWIKKELING EN ACHTERGRONDEN3 WIE ZIJN DE WERKENDE ARMEN IN NEDERLAND?4 ONDERZOEKSMETHODE5 WERKENDE MINIMA IN AMSTERDAM6 HOE KOMEN MENSEN IN WERKENDE ARMOEDE TERECHT?7 UIT DE ARMOEDE GEWERKT8 CONCLUSIES EN DISCUSSIEGERAADPLEEGDE

LITERATUURDe centrale onderzoeksvraag was: hoe zijn mensen in de situatie van werkende armoede terechtgekomen? En welke belemmeringen ervaren ze waardoor ze, hoewel werkend, niet of moeilijk uit armoede kunnen ontsnappen? Bestaand onderzoek over werkende armoede geeft wel inzicht in welke sociale categorieën het betreft, maar dit zegt weinig over hoe en waarom deze personen in deze situatie zijn terechtgekomen. We vroegen onze respondenten wat naar hun eigen mening de belangrijkste redenen waren waarom ze (in 2008) voor een bescheiden inkomen werkten (tabel 3). 


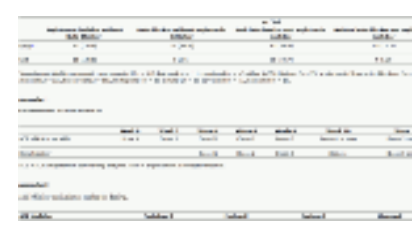

Tabel 3Click to view

Tabel 3

Door respondenten genoemde redenen voor 'werken

voor bescheiden inkomen' (meerdere antwoorden

mogelijk)

Fysieke en/of psychische gezondheidsbeperkingen, tekortschietende opleidingen en de zorg voor kinderen zijn de meest genoemde redenen die respondenten zelf geven voor hun situatie van werkende armoede.

Gezondheidsbeperkingen en zorgverplichtingen leiden ertoe dat mensen niet fulltime kunnen werken. Zeker als sprake is van laagbetaald werk en er geen ander inkomen in het huishouden is, leidt dit snel tot een situatie van werkende armoede. Er zijn ook respondenten die wel meer uren per week zouden willen werken, maar dit werk niet kunnen vinden. Behalve actuele redenen noemen respondenten ook redenen in het verleden die hen beperken in hun mogelijkheden en waardoor ze nu werkend arm zijn. Voorbeelden zijn problematische echtscheidingen, traumatische gebeurtenissen, perioden van ziekten, werkloosheid of de zorg voor kinderen, waardoor ze niet of beperkt aan de arbeidsmarkt deelnamen - en daarna niet goed konden terugkomen.

Vaak zijn het echter niet de afzonderlijk problemen, maar de combinatie van ongunstige factoren waardoor mensen in werkende armoede zijn terechtgekomen. Zo rapporteerden negen van de 34 respondenten die niet fulltime kunnen werken vanwege zorgverplichtingen daarnaast ook fysieke of psychische gezondheidsproblemen als belemmerende factor. Ook een tekortschietend opleidingsniveau speelt bij veel respondenten een rol op de achtergrond. In de rest van deze paragraaf verkennen we een aantal patronen waarom werkenden desondanks arm zijn.

Fysieke of psychische gezondheidsproblemen 
Bij 46 respondenten (42 procent van alle respondenten) speelden gezondheidsbeperkingen een rol bij het ontstaan van werkende armoede, vaak in combinatie met andere factoren. Het betreft zowel fysieke als psychische gezondheidsbeperkingen (en soms allebei). Enkele respondenten zijn formeel arbeidsongeschikt verklaard, maar willen desondanks werken.

Alleenstaande moeder (35 jaar) met twee kinderen, Turkse achtergrond, werd ontslagen wegens de crisis. Tegen haar verwachting in kon ze moeilijk werk vinden. $\mathrm{Na}$ een tijdje in de WW kwam ze in de bijstand. De bijstandsmedewerker zette haar zo onder druk om te solliciteren (bestempelde haar zelfs als 'lui') dat ze toenemend in de war raakte: 'Ik vond het vreselijk. Ik kreeg er echt nachtmerries van. [...] Ik heb een tijd gehad dat ik bij een psycholoog liep. Ik was psychisch helemaal in de war, ik vond het zo afschuwelijk dat mensen mij zo beleerden. Terwijl je zo je best doet en altijd hebt gewerkt...' Tegelijk lag ze in een scheiding met haar man en zorgde ze voor haar zoontjes, die ADHD en lichte verschijnselen van autisme hebben. Door deze combinatie van belemmeringen kan ze alleen parttime werken (drie dagen per week) en heeft ze een bescheiden inkomen.

Bij deze respondent wordt goed duidelijk dat de oorzaak van de problemen vaak een onontwarbare kluwen van beperkingen is: een moeilijke persoonlijke situatie (scheiding), zorg voor haar kinderen die ook beperkingen hebben, wellicht een zwakke psychische gesteldheid waardoor ze slecht tegen de druk vanuit de sociale dienst kan, waardoor ze uiteindelijk maar beperkt kon werken en ze in een situatie van werkende armoede terechtkwam. Wat hierbij oorzaak en gevolg is, is nauwelijks aan te geven. Kwam ze door haar moeilijke persoonlijke situatie en psychische gesteldheid niet tot solliciteren, waarna de sociale dienst haar onder druk zette? Of raakte ze (zoals ze zelf zegt) psychisch in de war omdat de sociale dienst haar zo onder druk zette en kon ze daarom niet solliciteren? Wel maakt dit voorbeeld goed duidelijk dat veel van onze respondenten te kampen hebben met een veelheid van beperkende factoren. Anderen kwamen door fysieke gezondheidsproblemen in een situatie van werkende armoede terecht. 
Alleenstaande vrouw (41 jaar). Ze is hoogopgeleid, maar kan door jarenlange drugs- en alcoholverslaving niet volledig werken. Ze is in 2006 gestopt met alcohol- en drugsgebruik: '... maar ja, als je twee jaar zoveel hebt gebruikt ben je nog zo vaag eigenlijk (...). Dus ik was niet echt in staat om te werken en dingen op te pakken'. Pas toen in 2008 haar WW-uitkering stopte, ging ze werken. Ze werkt 20 uur per week en vindt zelf dat ze niet meer uren kan werken: 'Nee, dat is echt de max. (...) Mijn baas vroeg op een gegeven moment of ik drie dagen per week wilde werken. Maar alleen het idee al. Ik ga echt dood van die 2,5 dag. Dat was meer dan zwaar genoeg. (...) De kleinste dingen zijn al enorm om te doen.'

Bij beide voorgaande gevallen hebben de betrokkenen zelf gezondheidsbeperkingen. Andere respondenten moeten vanwege gezondheidsproblemen van hun partner of kinderen veel tijd aan zorg besteden, waardoor ze minder kunnen werken en in een situatie van werkende armoede terechtkomen.

30-jarige man, woont samen met partner en twee kinderen, Egyptische achtergrond. Hij had samen met zijn vrouw een restaurant, totdat zij na een auto-ongeluk niet meer kon werken. Daarna probeerde hij het restaurant nog enige tijd alleen te runnen, maar dat was te veel werk. Daarom is het bedrijf nu omgevormd tot een bar, wat minder geld opbrengt.

\section{Tekortschietend opleidingsniveau, onvoldoende beheersing Nederlandse taal}

Een tweede reden waardoor veel respondenten in een situatie van werkende armoede terechtkomen, is een laag opleidingsniveau, een verkeerde of een in het buitenland gevolgde opleiding die hier niet wordt erkend. Bij respondenten met een migratieachtergrond speelt bovendien gebrekkige beheersing van de Nederlandse taal, waardoor ze zijn aangewezen op laaggekwalificeerd en dus laagbetaald werk. 45 respondenten (41 procent van alle respondenten) noemen een tekortschietend opleidingsniveau als reden voor het werken met een laag inkomen, meestal in combinatie met andere factoren. Een laag inkomen 
betekent, zoals gezegd, niet per definitie armoede; dit is vooral het geval als er geen andere partner c.q. een ander inkomen in het huishouden is.

Alleenstaande vrouw (33 jaar), Surinaamse achtergrond, ging met 15 jaar al van school en heeft alleen basisonderwijs afgerond. Na vele jaren zwart werk werkt ze sinds 2006 als arbeidstrainer op een sociale werkplaats. Ze kreeg dit werk via de sociale dienst. Zelf ziet ze het gebrek aan opleiding als reden waarom ze een bescheiden inkomen heeft: 'Nou, als ik mijn school had afgemaakt, dan had ik denk ik een betere baan kunnen vinden, maar ik ging met mijn stomme hoofd te veel naar andere mensen luisteren. Daar heb ik wel spijt van.'

32-jarige man, Marokkaanse achtergrond, woont sinds 2006 met vrouw en kind in Nederland. Sinds 2007 werkt hij als schoonmaker, maar vindt vanwege zijn gebrekkige taalbeheersing geen beter betaald werk. In Marokko had hij wel een hogere functie: 'Mijn vrouw heeft mij meerdere malen aangespoord om weer naar school te gaan, want in Marokko heb ik jarenlang gewerkt voor de gemeente.' Zijn werkgever geeft hem echter geen vrij om een opleiding te volgen en hij kan ook niet minder gaan werken. Omdat zijn vrouw niet werkt, leven ze van zijn inkomen. Het grootste probleem is de taal: 'Omdat ik de taal niet spreek en geen opleiding in Nederland heb gevolgd, maak ik geen kans bij sollicitaties.'

\section{Zorg voor kinderen}

Ook de zorg voor kinderen is een vaak genoemde reden waarom respondenten niet méér kunnen werken of ander werk kunnen doen waardoor ze meer zouden verdienen. 35 respondenten (32 procent) noemen dit als reden dat ze werkend arm zijn. Het zijn bijna allemaal vrouwen, merendeels alleenstaande moeders. Soms is de zorg voor kinderen de enige oorzaak van werkende armoede. De betrokkenen zijn minder gaan werken of gestopt met werken om meer tijd voor de kinderen te hebben. Vaak is dit een bewuste keuze, waarbij men de consequenties (een laag inkomen) op de koop toeneemt. Men ziet de tijd zonder of met minder werk en dus met minder inkomen als een 
'overbrugging' zolang de kinderen klein zijn. Gesproken wordt wel van 'subjectieve overbruggers': mensen werken een tijdje minder of niet vanwege een hoger doel (zorg voor kinderen, maar ook een opleiding of professionele heroriëntatie) maar realiseren zich vaak niet dat ze daarna moeilijk uit armoede kunnen ontsnappen (Leisering \& Leibfried, 1999: 91-98). De tijd zonder werk blijkt vaak een vicieuze cirkel waaruit ontsnapping moeilijk is.

Alleenstaande moeder (35 jaar) met twee kinderen, Marokkaanse achtergrond, werd na haar scheiding snel onder druk gezet door de sociale dienst om werk te zoeken. Aangezien ze redelijk geschoold is (havo/vwo) vond ze snel parttime werk als administratief medewerker bij een instelling voor jeugdgezondheidszorg. Ze wil niet fulltime werken vanwege hoge kosten voor kinderopvang, maar ook om bij haar kinderen te zijn: 'Je wilt er toch voor ze zijn, voordat je het weet zijn ze alweer wat ouder. Ja, wil ik wel veertig uur per week bij een baas doorbrengen? Dan kom je 's avonds thuis: de afwas, eten koken, voor je het weet is het al weer acht uur en moeten de kinderen naar bed. Wil ik wel zo leven? Wil ik wel de helft van hun leven missen?'

Deze respondent is een typische 'subjectieve overbrugger': ze accepteert een periode met minder werk en minder inkomen, maar verwacht dat het later beter wordt. Maar zoals uit de verhalen van respondenten blijkt, komt dit laatste niet altijd uit.

Alleenstaande moeder (53 jaar) met twee thuiswonende kinderen, Surinaamse achtergrond. Tijdens haar huwelijk bleef ze thuis om voor de kinderen te zorgen, vooral op wens van haar man. Na haar scheiding moest ze gaan werken, maar omdat ze zo lang niet had gewerkt was het moeilijk een baan te vinden. Ze vond alleen baantjes als oproepkracht in de thuiszorg en later als assistent-beveiliger. Beide banen waren parttime. Inmiddels zijn de kinderen groter en hoeft ze niet meer voor hen thuis te blijven, maar ze vindt geen werk waar ze meer uren kan werken en dus meer kan verdienen. 
In andere gevallen spelen naast de zorg voor kinderen nog andere redenen waarom respondenten minder werken en dus een gering inkomen hebben. $\mathrm{Er}$ zijn bijkomende factoren die de situatie compliceren. In 12 van de 35 gevallen is de combinatie van zorg voor kinderen en gezondheidsbeperkingen de reden waarom vrouwen minder kunnen werken en dus een laag inkomen hebben.
Alleenstaande moeder (46 jaar) met twee kinderen werkt parttime als assistent-bibliothecaresse. Ze werkt parttime omdat het psychisch niet goed gaat met haar kinderen en daardoor ook niet met haar zelf. Zelf verklaart ze haar bescheiden inkomen als volgt: 'De reden is gewoon de persoonlijke situatie, dus met de kinderen. Met de kinderen heb ik nogal wat toestanden gehad op psychisch gebied, [...] in therapie, intern opgenomen. [...] Ik kon daardoor niet langer werken. Ik moest [...] ze eigenlijk heel erg begeleiden, de dochters. Daardoor zelf psychisch ook niet helemaal [...], moest zelf ook therapie volgen.'

In elf gevallen speelt naast de zorg voor kinderen het lage opleidingsniveau een rol als oorzaak van werkende armoede. Soms hangen beide zaken nadrukkelijk samen: sommige vrouwen braken hun opleiding vanwege zwangerschap of de kinderen voortijdig af en ondervonden later dat ze daardoor aangewezen zijn op laagbetaald werk. Wanneer ze dan geen partner met een inkomen hebben en vanwege de kinderen niet fulltime kunnen werken, leidt dit al snel tot werkende armoede.
Alleenstaande moeder (33 jaar) met één kind, Turkse achtergrond, heeft haar mbo-opleiding niet afgemaakt, omdat ze al een goede baan had en aardig verdiende. Tijdens de zwangerschap stopte ze met werken. Daarna bleef ze vier jaar thuis bij haar kind. Toen ze weer werk ging zoeken, bleek het moeilijk om een baan op niveau te vinden: 'Ik heb er heel lang uitgelegen. Ik heb ervaring in het bankwezen en vroeger telde dat. Maar ik heb geen diploma's en daar wordt nu op gelet.'

\section{Geen ander werk kunnen of willen vinden}


Zestien respondenten (15 procent) geven aan dat ze graag ander of méér werk willen doen, maar dat ze dat niet te kunnen vinden. Hier ligt het probleem dus niet zozeer in persoonlijke omstandigheden maar in de krappe arbeidsmarkt. Opmerkelijk is dat velen van hen bij de overheid of andere publieke instanties werken (zoals een baliemedewerkster bij een museum of een voedingsassistente in een ziekenhuis). Diverse respondenten zeggen dat ze vanwege bezuinigingen niet méér uren kunnen werken:
Alleenstaande moeder (51 jaar) met één kind, werkt 24 uur per week als medewerker bij een re-integratiebedrijf en ontvangt daarnaast een aanvullende uitkering. Nu haar kind groter is, wil ze graag meer werken: 'Nou, met mijn huidige baan kan ik niet meer uren krijgen. Omdat er geen geld meer is, dus een uitbreiding van mijn uren zit er helemaal niet meer in. Ik zou graag vier uur meer willen maar dat lukt nu niet.'

Naast degenen die wel meer zouden willen werken, zijn er ook respondenten die om uiteenlopende redenen niet meer willen werken, bijvoorbeeld omdat ze het werk nu al zwaar vinden, ze meer vrije tijd willen of omdat ze vrezen er financieel op achteruit te gaan als ze meer gaan werken. Zeven respondenten vrezen financieel achteruit te gaan als ze meer gaan werken, bijvoorbeeld vanwege hoge kosten van de kinderopvang, of dat ze daardoor hun arbeidsongeschiktheidsuitkering of bijzondere bijstand zouden verliezen. Eén respondent bevestigt dat ze nu met werk inderdaad minder inkomen heeft dan eerder met een uitkering plus diverse toeslagen.

\section{Traumatische gebeurtenissen}

De oorzaken van werkende armoede kunnen ook in het verleden liggen. Acht respondenten zeggen dat ze langdurig ziek of werkloos zijn geweest en daardoor nu weinig kans hebben op een betere en beter betaalde baan. Eveneens acht respondenten zeggen dat ze door een problematische scheiding maar beperkt kunnen werken en dus een laag inkomen hebben. Bij zeven respondenten vloeit de huidige problematische situatie direct of indirect voort uit traumatische gebeurtenissen in het verleden. Het betreft soms geweld en misbruik in de jeugd, soms huiselijk geweld tijdens het huwelijk of het verlies van een kind. 
Alleenstaande moeder (34 jaar) met één kind vertelt dat ze samen met haar moeder en zusje werd mishandeld door haar vader: 'Een heel vervelende jeugd gehad ... ehm ... waar dus ook mishandeling bij kwam kijken van mijn vader. (Het) was allemaal bij de politie bekend en we hebben ook in een Blijf van mijn lijf-huis gezeten.' Haar vader overleed toen zij 17 was. Eerst was ze opgelucht, maar daarna kwam de grote klap en kon het haar niets meer schelen. Ze heeft toen haar school niet afgemaakt en zat met een bijstandsuitkering thuis. Inmiddels is ze alleenstaande moeder en heeft ze een chronische ziekte waardoor ze snel moe is en niet fulltime kan werken.

Alleenstaande vrouw (51 jaar), Bulgaarse achtergrond, werd tijdens haar huwelijk geslagen: 'Toen kwam de echtscheiding en moest ik voor mezelf zorgen. De scheiding was een probleem omdat hij mij mishandelde. Daardoor kwam ik terecht bij de vrouwenopvang en kon ik niet werken. Het was ook een probleem bij het werk zoeken. Ik was in de war door alles wat er gebeurd was en ik was heel onstabiel en niet assertief genoeg.' Later ging het beter met haar en kreeg ze parttime werk.

Traumatische ervaringen in het verleden zijn veelal niet de enige oorzaak van werkende armoede. Meestal is sprake van een combinatie met andere ongunstige factoren zoals gezondheidsklachten of gebrekkige taalbeheersing.

\section{UIT DE ARMOEDE GEWERKT}

\section{Go to section..}

TOPSUMMARY1 INLEIDING2 WERKENDE ARMOEDE: ONTWIKKELING EN ACHTERGRONDEN3 WIE ZIJN DE WERKENDE ARMEN IN NEDERLAND?4 ONDERZOEKSMETHODE5 WERKENDE MINIMA IN AMSTERDAM6 HOE KOMEN MENSEN IN WERKENDE ARMOEDE TERECHT?7 UIT DE ARMOEDE GEWERKT8 CONCLUSIES EN DISCUSSIEGERAADPLEEGDE

LITERATUURZoals gezegd, hadden slechts 20 respondenten (18 procent) zich in 2009 'uit de armoede gewerkt' (Hoff 2010). Ze werkten nog steeds, maar waren niet meer arm. We vroegen hen hoe zij uit de armoede konden ontsnappen. In theorie kunnen huishoudens op twee manieren uit de armoede ontsnappen: dankzij een hoger huishoudinkomen door hetzij zelf meer te gaan 
werken of meer te verdienen, dan wel een partner te krijgen die een extra inkomen in het huishouden inbrengt, of door een verandering van de huishoudsamenstelling waardoor de relevante armoedegrens verandert (terwijl het inkomen gelijk blijft). 9

9.Verandering van de huishoudomvang en -samenstelling kan zowel een oorzaak van armoede zijn als de reden dat men niet meer arm is. Het eerste in bijvoorbeeld het geval wanneer een alleenstaande een kind krijgt. Als eenoudergezin ligt de armoedegrens hoger en is men met hetzelfde inkomen opeens 'arm'. Hetzelfde gebeurt wanneer een alleenstaande gaat samen wonen (althans als de partner geen of slechts een gering eigen inkomen heeft). Omgekeerd kan verandering van de huishoudsamenstelling ook de reden zijn dat men niet meer arm is. Als bijvoorbeeld het laatste kind van een alleenstaande moeder uit huis gaat en ze geen eenoudergezin meer is, is sprake van een lagere armoedegrens en is ze met hetzelfde inkomen niet meer arm. Zulke variaties van de huishoudomvang en -samenstelling zijn een belangrijke oorzaak van transities in en uit armoede.

Dit laatste komt bij onze respondenten niet voor. In alle gevallen konden onze respondenten uit de armoede ontsnappen door een gestegen huishoudinkomen. Tabel 4 laat zien welke redenen respondenten noemden waardoor ze in 2009 niet meer arm waren.

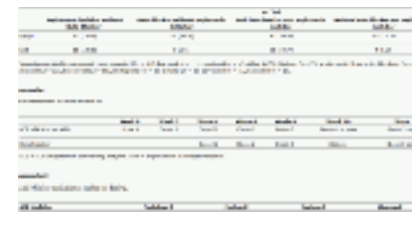

Tabel 4Click to view

Tabel 4

Waarom in 2009 een hoger inkomen gekregen?

Alle respondenten die er in 2009 financieel op vooruitgingen, benadrukken dat het om kleine bedragen gaat. 'Het is normaal dat je ieder jaar wat meer verdient dan het voorgaande jaar (€30 per maand erop vooruit gegaan)', stelt een 32jarige moeder van twee kinderen, die drie dagen per week als pedagogisch medewerker werkt. Een 36-jarige alleenstaande moeder met Surinaamse achtergrond vertelde dat ze alleen door een hogere periodiek meer inkomen 
had gekregen. Deze uitspraken laten zien dat het 'ontsnappen uit de armoede' soms een kwestie van enkele euro's meer is. Dit verklaart ook waarom diverse respondenten, die volgens formele registraties niet meer arm waren, zelf geen verbetering van hun financiële situatie ervoeren en dus zeiden nog steeds arm te zijn.

Acht respondenten (van de 20) gingen er in 2009 financieel op vooruit omdat ze in dezelfde baan méér uren konden werken, mede omdat de kinderen groter werden. Bijvoorbeeld een 48-jarige vrouw die samenwoont met haar partner en kinderen: 'Ik ben binnen hetzelfde bedrijf wat meer uren gaan werken. Eerst was dit 25 uur en nu is dat (...) 30 uur per week'. Een 53-jarige alleenstaande moeder met Surinaamse achtergrond, die eerder door gezondheidsklachten minder was gaan werken, vertelt: ' $l k$ kreeg fulltime werk in de kinderopvang, wat ik fysiek weer aankon. Dus ander werk en meer uren. Ook was mijn dochter ouder waardoor ik minder vaak thuis hoefde te zijn en een fulltime baan kon nemen'. Zeven respondenten waren in 2009 niet meer arm omdat ze in een nieuwe baan meer verdienden. Twee van hen kregen beter betaald werk na afronding van een opleiding. Een 47-jarige alleenstaande man kon in een andere baan méér werken: 'Wat ik eerst deed (art support) was leuker, maar in de zorg verdien ik meer'. Een 42-jarige alleenstaande moeder met twee kinderen vertelde dat ze door eerdere werkervaring een beter betaalde baan had gekregen waardoor ze niet meer arm was.

Drie respondenten kregen het in 2009 financieel beter door hogere inkomsten uit eigen bedrijf. Een van hen is beeldhouwster die twee beelden verkocht 'voor een hoop geld'. Een andere informant was een 34-jarige vrouw met Surinaamse achtergrond die in 2008 met kinderopvang aan huis was begonnen. In 2009 stegen de inkomsten doordat ze 'meer kinderen kon gaan verzorgen. Ik leerde meer mensen kennen en die vertelden door wat ik deed. Zo kon ik meer kinderen verzorgen en meer geld verdienen'. Bij twee van de 20 respondenten die in 2009 uit werkende armoede ontsnapten, kwam dit niet doordat ze méér gingen werken of verdienen, maar doordat er een extra inkomen in het huishouden bij kwam. Een 54-jarige vrouw trouwde in 2008. Door het gezamenlijke inkomen van haar en haar partner was ze niet meer arm. Hetzelfde geldt voor een 46-jarige alleenstaande moeder met een 
gehandicapt volwassen kind thuis. Doordat het kind een Wajong-uitkering kreeg én de moeder meer ging werken, is ook dit huishouden niet meer arm.

We vroegen de respondenten die het in 2009 financieel beter hadden gekregen, of ze hierbij steun van derden hebben gekregen. De meesten hadden weinig of geen steun van derden gekregen. Slechts een handvol respondenten had 'veel' steun gekregen van de gemeente of van uitkeringsinstanties (sociale dienst, UWV). Als respondenten al steun van derden kregen, ging het eerder om informele contacten (collega's, vrienden, familie of een werkgever, een mentor van een opleiding en diverse zorginstellingen). De meeste respondenten zeggen dat ze geen behoefte hebben aan steun van derden, al zeiden sommigen dat ze meer of andere ondersteuning van de gemeente hadden willen krijgen (al weten we niet wat voor steun zij hadden verwacht).

\section{CONCLUSIES EN DISCUSSIE}

Go to section.

TOPSUMMARY1 INLEIDING2 WERKENDE ARMOEDE: ONTWIKKELING EN ACHTERGRONDEN3 WIE ZIJN DE WERKENDE ARMEN IN NEDERLAND?4 ONDERZOEKSMETHODE5 WERKENDE MINIMA IN AMSTERDAM6 HOE KOMEN MENSEN IN WERKENDE ARMOEDE TERECHT?7 UIT DE ARMOEDE GEWERKT8 CONCLUSIES EN DISCUSSIEGERAADPLEEGDE

LITERATUURWerkende armen komen niet alleen voor in marginale verzorgingsstaten zoals de Amerikaanse, maar toenemend ook in Nederland en elders in Europa. Het adagium 'werk moet lonen' komt niet altijd overeen met de werkelijkheid. Ook Nederland telt een groeiend aantal werkende armen. Telde Nederland midden jaren negentig nog krap 150.000 werkende minima, in 2014 was dat aantal opgelopen tot 366.000. Dit betekent dat bijna een op de 20 werkenden in Nederland (4,8 procent) onder de armoedegrens leeft (Josten 2007; Snel \& De Boom 2008; Wildeboer Schut \& Hoff 2016). Binnen Europa komt Nederland hiermee op de vijfde plaats als land met verhoudingsgewijs de minste werkende armen. In veel andere EU-landen ligt het aandeel werkende armen dus nog hoger. Dit onderzoek is uitgevoerd in Amsterdam. De directe aanleiding voor dit onderzoek waren cijfers waaruit bleek dat het aandeel werkende armen in Amsterdam nog aanzienlijk hoger lag dan landelijk gemiddeld. 
Waarom het aantal werkende armen in Nederland en in Europa toeneemt, wordt uit de literatuur niet duidelijk. Waarschijnlijk spelen economische, beleidsmatige en maatschappelijke factoren hierbij een rol. De opkomst van de postfordistische diensteneconomie leidt tot een groeiend aantal laagbetaalde en flexibele banen, waardoor werkenden gevangen blijven in armoede. Ook zijn vakbonden zwakker in postfordistische diensteneconomieën. In landen waar vakbonden zwakker zijn, zouden er meer werkende armen zijn. Verder zouden mondialisering en de komst van arbeidsmigranten een drukkend effect op de lonen hebben en tot werkende armoede kunnen leiden. Specifiek voor Nederland speelt ten slotte het hoge aantal parttime werkenden. Verricht men tijdelijk of parttime laagbetaald werk, dan is er grote kans op werkende armoede - zeker als er niet meer inkomens in het huishouden zijn. Toch had de helft van onze respondenten een vast contract en werkt bijna de helft van hen 30 uur per week of meer. Ook werkten onze respondenten niet alleen in laagbetaalde dienstenbaantjes, maar ook in andere sectoren zoals industrie, vervoer, horeca en ook publieke dienstverlening. Sommige respondenten hadden professionele beroepen (zoals activiteitenbegeleider of doktersassistente) maar waren door parttime dienstverbanden toch arm.

Een belangrijke vraag is in hoeverre het activerende overheidsbeleid van de afgelopen decennia een rol speelt bij het groeiende aantal werkende armen. Worden mensen met geringe arbeidsmarktkansen, die voorheen de sociale bescherming van een uitkering genoten, de arbeidsmarkt op gedrongen zonder dat ze uit de armoede kunnen ontsnappen? Dit onderzoek bevestigt deze vrees niet. Slechts een minderheid van de respondenten (40 procent) kwam vanuit een uitkeringssituatie in werkende armoede terecht en slechts enkelen van hen (negen van 34 personen) hadden enige of sterke druk ervaren om aan het werk te gaan. De andere respondenten waren in werkende armoede ingestroomd vanuit ander werk (49 procent) of direct vanuit onderwijs of anderszins nietwerkend (10 procent). Met ruim honderd respondenten is dit onderzoek echter te kleinschalig om betrouwbare uitspraken te kunnen doen over de determinanten van werkende armoede in Nederland. Hiervoor is meer grootschalig onderzoek onder werkende armen noodzakelijk.

De kracht van het onderhavige onderzoek ligt in de verhalen van respondenten: hoe zij in de situatie van werkende armoede terechtkwamen en hoe sommigen 
van hen hieruit wisten te ontsnappen. Wat hierbij vooral opvalt, is dat bij de meeste respondenten sprake is van een combinatie van ongunstige factoren een 'cumulatie van ellende', zoals Schuyt (1987) ooit zei - waardoor ze in werkende armoede terechtkwamen. Een gering human capital (opleiding, talenkennis, enz.) speelt bij veel respondenten een rol op de achtergrond. Hierdoor zijn ze aangewezen op laagbetaalde arbeid. Als men ook nog parttime werkt én er geen ander inkomen in het huishouden binnenkomt, zit men al snel in een situatie van werkende armoede. Daarnaast werken veel respondenten om uiteenlopende, merendeels persoonlijke redenen parttime: fysieke of psychische gezondheidsproblemen, zorg voor kinderen, die soms zelf ook weer gezondheidsbeperkingen hebben, traumatische gebeurtenissen, ziektegeschiedenissen, zorgtaken, of een problematische scheiding in het verleden. Ook al is de directe aanleiding om parttime te werken niet meer urgent, het lukt hun niet om meer of beter betaald werk te krijgen. Dit geldt vaak ook voor degenen (met name vrouwen) die er bewust voor kozen tijdelijk minder te werken en een lager inkomen te accepteren om voor de kinderen te zorgen. Zoals de Duitse armoedeonderzoekers Leisering en Leibfried (1999) stelden, lukt het deze 'subjectieve overbruggers' niet altijd om later uit armoede te ontsnappen.

Een beperkt aantal respondenten $(N=20)$ lukte het wel om uit de situatie van werkende armoede te ontsnappen: ze waren in 2008 werkend arm, een jaar later werkten ze nog steeds en waren ze (ook in hun eigen beleving) niet meer arm. De belangrijkste reden om uit werkende armoede te ontsnappen, was om in de huidige baan dan wel in een nieuwe baan meer te werken of meer te verdienen, wat vaak mogelijk werd door verminderde gezondheidsbeperkingen of zorgverplichtingen. Wel benadrukten de meeste respondenten dat de inkomensstijging in 2009 zeer gering was. Dit verklaart waarschijnlijk ook waarom diverse respondenten die volgens gemeentelijke registraties in 2009 niet meer arm waren, dit zelf niet als zodanig beleefden. Ook met 1 euro meer per maand kan men uit armoede 'ontsnappen', maar mensen ervaren dit zelf niet als een financiële verbetering. Deze kloof tussen de geregistreerde en ervaren werkelijkheid van armoede laat zien dat we vraagtekens moeten zetten bij de in armoedeonderzoek veel gebruikte inkomensstatistieken. In de beleving van betrokkenen is armoede vaker duurzaam en minder tijdelijk dan de gebruikelijke inkomensstatistieken suggereren. Kwalitatief onderzoek hoe 
mensen hun leven in gemarginaliseerde posities zelf beleven blijft daarom noodzakelijk.

\section{GERAADPLEEGDE LITERATUUR}

Go to section

TOPSUMMARY1 INLEIDING2 WERKENDE ARMOEDE: ONTWIKKELING EN ACHTERGRONDEN3 WIE ZIJN DE WERKENDE ARMEN IN NEDERLAND?4 ONDERZOEKSMETHODE5 WERKENDE MINIMA IN AMSTERDAM6 HOE KOMEN MENSEN IN WERKENDE ARMOEDE TERECHT?7 UIT DE ARMOEDE GEWERKT8 CONCLUSIES EN DISCUSSIEGERAADPLEEGDE LITERATUURAndre $\beta, H . J$. en Lohmann, H.Year: (2008). Introduction: the working poor in Europe. In H.J.Andreß en H.Lohmann (eds.) The Working Poor in Europe. Employment, Poverty and Globalization. Cheltenham: Edward Elgar (pp. 1-14)

2. Bardone, L. en Guio, A.C.Year: (2005). In-work poverty. New commonly agreed indicator at the EU level.Statistics in Focus, 5/2005.

3. de Beer, P.Year: (1999). Werk en armoede. In SCP/CBS Armoedemonitor 1999. Den Haag: SCP (pp. 111-136).

4. Ehrenreich, B.Year: (2002). Nickel and Dimed: Undercover in Lowwage America.London: Granta Books.

5. Esping-Andersen, G.Year: (1990). The Three Worlds of Western Welfare Capitalism. Cambridge: Polity Press.

6. Esping-Andersen, G.Year: (1993). Post-industrial class structures: an analytical framework. In G.Esping-Andersen (ed.), Changing classes. Stratification and Mobility in Post-Industrial Societies. London: Sage (pp. 7-31).

7. Gilbert, N.Year: (2002). Transformation of the Welfare State. The Silent Surrender of Public Responsibility. Oxford: Oxford University Press,

8. Hoff, S.Year: (2010). Uit armoede werken. Omvang en oorzaken van uitstroom uit armoede.Den Haag: SCP.

9. Hoff, S., Wildeboer Schut, J.M., Goderis, B. en Vrooman, J.C.Year: (2016). Armoede in kaart 2016. Den Haag: SCP.

10. Josten, E.Year: (2007). Werkende armen. In SCP/CBS, Armoedemonitor 2007. Den Haag: SCP (pp. 77-93).

11. Leisering, L. en Leibfried, S.Year: (1999). Time and Poverty in Western Welfare States. United Germany in Perspective. Cambridge: Cambridge University Press.

12. Levecque, K. en Vranken, J.Year: (2000). Armoede, sociale uitsluiting en sociale insluiting: van theoretisch model naar wetenschappelijke praktijk. In Vranken, J. e.a. (red.), Armoede en sociale uitsluiting, Jaarboek 2000. Leuven: Acco.

13. Lohmann, H. en Andre $\beta$, H.J.Year: (2008). Explaining in-work poverty within and across countries. In Andre $\beta$, H.J. en Lohmann, H. (eds.) The Working Poor in Europe. Employment, Poverty and Globalization. Cheltenham: Edward Elgar (pp. 293-313).

14. Newman, K.S. Year: (1999). No Shame in my Game. The Working Poor in the Inner City. New York: Vintage Books.

15. van de Pol, W.Year: (2016). Wie arm is in Nederland blijft dat vaak ook. Trouw, d.d. 1 maart 2016. .

16. Schraad-Tischler, D. en C.SchillerYear: (2016). Social Justice in the EU - Index Report 2016 Social Inclusion Monitor Europe. Gütersloh: Bertelsmann Stiftung (www.bertelsmann-stiftung.de)

17. Stoker, E.Year: (2010). Plezier? Je doet dit werk omdat het moet.De Volkskrant, d.d. 19 mei 2010. 
18. Schuyt, C.J.M.Year: (1987). 'Maatschappelijke ongelijkheid, een sociologische interpretatie'. In: Berting, J. (red.), Maatschappelijke ongelijkheid: de overheid een zorg?. Utrecht: Veen uitgevers.

19. SCP/CBSYear: (2010)Armoedesignalement 2010. Den Haag: SCP.

20. Snel, E., Engbersen, G. en Vrooman, J.C.Year: (2000). 'Arm Nederland: verandering en bestendiging van armoede'. In Engbersen, G., Vrooman, J.C. en Snel, E. (red.). Balans van het armoedebeleid. Vijfde jaarboek armoede en sociale uitsluiting. Amsterdam: Amsterdam University Press (pp. 13-52).

21. Snel, E., de Boom, J. and Engbersen, G. Year: (2008). The silent transformation of the Dutch welfare state and the rise of in-work poverty. In Andre $\beta$, H.J. en Lohmann, H. (eds.), The Working Poor in Europe. Cheltenham: Edward Elgar (pp. 124-154).

(http://repub.eur.nl/res/pub/18432/chapter\%20silent\%20transformation. pdf).

22. Snel, E. en de Boom, J.Year: (2008). Welfare state reform and in-work poverty in the Netherlands. Paper prepared for the conference 'Work, poverty and inequality in the 21th century', Summer 2008 meeting of the RC28 at Stanford University (California, USA), August 6-9 2008 (http://repub.eur.nl/res/pub/15688/working\%20poor\%20Netherlands.pdf ).

23. Snel, E., Slot, J. en Nottelman, N.Year: (2012). Werkende minima in Amsterdam. Kwalitatief onderzoek naar situatie van werkende armen in Amsterdam. Amsterdam: Dienst Onderzoek en Statistiek (http://www.ois.amsterdam.nl/pdf/2012 werkende\%20minima\%20in\%2 Oamsterdam.pdf).

24. Tinnemans, W.Year: (2009). Onzeker bestaan. Leven aan de rafelrand van de arbeidsmarkt. Amsterdam: Nieuw Amsterdam.

25. Wildeboer Schut, J.M. en Hoff, S. Year: (2016). Een lang tekort. Langdurige armoede in Nederland. Den Haag: SCP. 